\title{
STRATEGI PEMASARAN PERBANKAN SYARIAH DI BANYUMAS
}

\author{
Encep Saepudin $^{1}$, Safitri Mukarromah ${ }^{2}$ \\ ${ }^{1}$ Fakultas Agama Islam Universitas Muhamadiyah Purwokerto, Email : encep.1972@gmail.com \\ ${ }^{2}$ Fakultas Agama Islam Universitas Muhamadiyah Purwokerto, Email : \\ safitri.mukarromah06@gmail.com
}

\begin{abstract}
ABSTRAK
Tujuan penelitian ini adalah Bank Muamalat Indonesia (BMI), Bank Syariah Mandiri (BSM), Bank Jateng Syariah, Bank BRI Syariah, dan Bank BNI Syariah tidak memasang iklan di koran Radar Banyumas dan Satelit Post selama periode November 2016 sampai dengan Februari 2017. Penelitian menemukan berita Bank BSM, Bank BRI Syariah, Bank BNI Syariah, dan Bank Jateng Syariah selama bulan Februari 2017. Pemberitaan ini cukup mendukung publikasi bank-bank syariah bersangkutan pada masyarakat. Disarankan bank-bank syariah yang beroperasi di Banyumas menjalin kerjasama untuk memasang iklan bersama di koran agar makin dikenal masyarakat Banyumas.
\end{abstract}

Kata-Kata Kunci : Bank Syariah, Iklan, Koran

\begin{abstract}
The purpose of this study is Bank Muamalat Indonesia (BMI), Bank Syariah Mandiri (BSM), Bank Jateng Syariah, Bank BRI Syariah, and Bank BNI Syariah does not advertise in the Radar Banyumas newspaper and Satelit Post during the November 2016 period until February 2017. Research find the news of Bank BSM, BRI Syariah Bank, Bank BNI Syariah, and Central Java Syariah Bank during February 2017. This news is sufficient to support the publication of the relevant Islamic banks in the community. It is recommended that Islamic banks operating in Banyumas establish cooperation to advertise together in newspapers so that the Banyumas people will become more familiar.
\end{abstract}

Keywords : Islamic Bank, Advertising, Newspaper. 


\section{Islãmadîna \\ JURNAL PEMIKIRAN ISLAM}

Volume 19, No. 2, September $2018: 41-58$

\section{PENDAHULUAN}

Perkembangan bank syariah di Indonesia memasuki tahun ke-25 sejak pendirian bank syariah pertama, yaitu Bank Muamalat Indonesia (BMI) pada tahun 1991. Hingga kini, jumlah bank umum syariah (BUS) sebanyak 13 bank dan unit usaha syariah (UUS) sebanyak 34 bank berdasarkan Statistik Perbankan Syariah (SPS) 2016 (Otoritas Jasa Keuangan, 2016). Pangsa pasar perbankan syariah sekitar 4,87 persen dari total industri perbankan nasional pada 2015 (www.antaranews.com, 2016). Persensate tersebut belum mencapai target yang diharapkan berdasarkan Cetak Biru Pengembangan Perbankan Syariah Indonesia sebesar 15 persen pada tahun 2010 (Bank Indonesia, 2007). Belum terealisasinya target tersebut disebabkan masih banyak menyimpan permasalahan yang perlu diurai untuk dibenahi bersama seluruh pemangku kepentingan (stakeholders).

Otoritas Jasa Keuangan (OJK) mencatat tujuh tantangan perkembangan perbankan syariah yang harus dihadapi di masa depan, yaitu : pertama, sinergi OJK dengan pemerintah; kedua, permodalan; ketiga, biaya mahal; keempat, produk belum variatif; kelima, kualitas sumberdaya manusia minim; keenam, keterbatasan pengetahuan masyarakat terhadap bank syariah; dan ketujuh, pengaturan dan pengawasan yang masih terbatas (tempo.co, 2015). Tentunya sudah banyak model yang diusulkan dalam menghadapi tantangan di atas, salah satunya melalui promosi pada seluruh stakeholders, dari bagi kalangan internal maupun eksternal. Salah satu tujuan promosi adalah sebagai media komunikasi dengan maksud mempengaruhi obyek promosi, baik pegawai sebagai bagian manajemen bank syariah, maupun masyarakat sebagai konsumen (Martutik, 2013).

Iklan merupakan bauran promosi paling efektif karena mampu menjaring konsumen dalam jumlah besar dalam wilayah berbeda dan memiliki pesan yang dapat disimpan dalam tempo lama (Kartika, dkk, 2016). Salah satu media pemasangan iklan adalah koran. Produsen mengemas iklan dengan kombinasi kalimat singkat dan visual agar menarik perhatian pembaca (Juniar, 2013). Media cetak, termasuk koran, memiliki dua keunggulan sebagai media pemasangan iklan karena mampu menyampaikan pesan yang kompleks dan menjangkau sasaran yang luas (Martutik, 2013). Dalam lingkup lokal, pangsa pasar perbankan syariah di wilayah kerja Otoritas Jasa Keuangan (OJK) Perwakilan Purwokerto mencapai 5,98 persen, dengan aset sebesar Rp.1,3 triliun per Desember 2014. (bisnis.com, 2015). Bank-bank syariah yang beroperasi di wilayah kerja kantor OJK ini diantaranya adalah Bank BMI, Bank Syariah Mandiri (BSM), Bank Jateng Syariah, Bank BRI Syariah, dan Bank BNI Syariah.

Berdasarkan data di atas dapat dirumuskan permasalahan dalam penelitian ini adalah seberapa banyak frekuensi pemasangan iklan bank-bank syariah tersebut di kedua koran lokal, jenis iklan yang dipilih, serta konten iklan pada koran Radar Banyumas dan Satelit Post selama periode November 2016 - 
Februari 2017.

Tujuan penelitian ini adalah mengetahui frekuensi pemasangan iklan bank-bank syariah tersebut di kedua koran lokal, mengetahui jenis iklan yang dipilih, serta mengetahui konten iklan pada koran Radar Banyumas dan Satelit Post selama periode November 2016-Januari 2017. Berdasarkan tujuan penelitian ini, maka manfaat yang akan dihasilkan adalah dapat mengembangkan pemasaran melalui iklan media cetak dengan frekuensi, jenis iklan, dan konten iklan yang sudah direncanakan dengan baik teoritis maupun praktis.

\section{TINJAUAN PUSTAKA}

\section{Pemasaran}

Pengertian pemasaran adalah proses perencanaan dan pelaksanaan konsepsi, penetapan harga, promosi, dan distribusi ide, barang, dan jasa untuk menciptakan nilai tukar yang memuaskan tujuan individu dan organisasi (Lengkey, 2014). Pemasaran bertujuan memaksimumkan banyak hal dalam transaksi perdagangan barang (goods) dan jasa (services) sebagai berikut : pembelian barang dan jasa, kepuasan pelanggan melalui pelayanan yang sejalan dengan kebutuhan pelanggan, pilihan produk barang dan jasa, kemudahan memperoleh barang dan jasa, serta penciptaan iklim (Melina Banggawaliman, 2013). Promosi adalah bauran pemasaran dan beberapa hal yang perlu diperhatikan dalam promosi adalah mengidentifikasi target audiens, menentukan tujuan promosi, mengembangkan pesan, dan menentukan pilihan bauran dengan pilihan sebagai berikut : iklan, personal selling, sales promotion, public relations, word of mouth, dan direct marketer (Ratnasari, 2011).

2. Iklan

Iklan bertujuan memperkenalkan, mengingatkan, mengajak, membujuk, serta menjaga hubungan dengan konsumen agar tertarik pada produk yang ditawarkan. Lebih lanjut dijelaskan bahwa iklan memiliki dua dampak, yaitu menarik calon konsumen menjadi konsumen loyal dalam jangka waktu tertentu dan mengembangkan sikap positif calon konsumen yang diharapkan dapat menjadi pembeli yang potensial masa datang (Dewi, 2012).

Iklan yang berhasil terletak pada pengemasan pesan yang menarik, menjangkau para pelanggan potensial dalam suatu wilayah, dan pada waktu yang tepat (Wijaya, 2014). Iklan memiliki empat tujuan, yaitu Informatif (menciptakan kesadaran dan pengetahuan tentang produk baru atau ciri baru produk yang sudah ada), persuasif (menciptakan kesukaan, preferensi, keyakinan dan pembelian suatu produk atau jasa), pengingat (merangsang pembelian produk dan jasa kembali), serta menyakinkan pembeli bahwa mereka telah melakukan pilihan yang tepat (Lengkey, dkk, 2014).

Bentuk bentuk iklan koran adalah iklan baris, iklan display, dan 


\section{Islãmadîna \\ JURNAL PEMIKIRAN ISLAM}

advetorial. Iklan baris adalah iklan yang hanya terdiri dari pesan pesan komersial yang berhubungan dengan kebutuhan pengiklan. Iklan display adalah iklan yang mempunyai ukuran tertentu dan sangat bervariasi, tetapi biasanya minimal 2 kolom, mulai dari 2 kolom kali 5 sentimeter hingga 1/4, 1/2, dan 1 halaman penuh berwarna. Iklan advetorial adalah iklan produk/jasa yang disajikan dalam bentuk berita/narasi.

3. Koran

Koran atau suratkabar memiliki peran penting sebagai media bagi iklan yang umumnya berasal dari perusahaan kecil lalu mengembang dengan pesat dan menyebar di seluruh daerah, dan surat kabar bukan hanya digunakan untuk iklan komersial saja tetapi juga bisa digunakan untuk iklan yang berjenis layanan masyarakat. Namun tidak sedikit perusahaan besar memanfaatkan surat kabar sebagai media untuk beriklan (Lengkey, 2014).

Distribusi koran masih tersebar dengan cukup baik di Indonesia karena jumlah penerbit di setiap provinsi masih terus meningkat dari tahun ke tahun. Koran masih menjadi industri yang menjanjikan bagi pemilik modal sehingga aliran modal ke industri ini masih terus mengalir. Hal ini membuktikan bahwa media cetak tetap merupakan bentuk media yang paling mudah diakses oleh warga negara (Nugroho, dkk, 2012).

4. Bank syariah

Bank adalah badan usaha yang menghimpun dana dari masyarakat dalam bentuk simpanan dan menyalurkannya kepada masyarakat dalam bentuk kredit dan/atau bentuk lainnya dalam rangka meningkatkan taraf hidup rakyat. Perbankan Syariah adalah segala sesuatu yang menyangkut tentang Bank Umum Syariah (BUS) dan Unit Usaha Syariah (UUS), mencakup kelembagaan, kegiatan usaha, serta cara dan proses dalam melaksanakan kegiatan usahanya. Bank Umum Syariah adalah bank syariah yang dalam kegiatannya memberikan jasa dalam lalu lintas pembayaran (Undang-undang Nomor 21 Tahun 2008 tentang Perbankan Syariah).

\section{METODE PENELITIAN}

Kajian terhadap iklan ini menggunakan pendekatan kualitatif karena lima pertimbangan, yaitu data penelitian adalah data iklan, mengumpulkan dan menganalisis data, tidak bermaksud menguji hipotesis, menganalisis data secara induktif, dan frekuensi, jenis, dan konten yang menjadi perhatian (Martutik, 2013). Metode penelitian menggunakan metode deskriptif yaitu menjelaskan keadaan atau peristiwa yang sedang diteliti dengan menggambarkan objek pada saat yang sama berdasarkan fakta. Penelitian ini tidak mencari dan menjelaskan hubungan, tidak menguji hipotesis maupun membuat prediksi (Lengkey, 2014, merujuk Rakhmat, 2001). Dalam penelitian ini jenis data yang digunakan adalah data primer dan sekunder. Sumber data primer adalah koran Radar Banyumas dan Satelit Post. Sumber data sekunder adalah buku, data 
perkembangan bank syariah dari Otoritas Jasa Keuangan (OJK), data Banyumas Dalam Angka 2016, serta jurnal yang berkaitan dengan penelitian ini.

Teknik analisis data dalam penelitian ini adalah teknik analisa deskriptif kualitatif, yakni data yang terkumpul diklasifikasi dan diolah dengan menggunakan tabel frekuensi dan presentase kemudian dideskripsikan dalam bentuk kalimat dengan rumus (Lengkey, 2014) sebagai berikut :

$$
\begin{gathered}
\mathrm{P}=f / n \times 100 \% \\
\text { Keterangan : } \\
\mathrm{P}=\text { Persentase } \\
\mathrm{f}=\text { frekuensi } \quad 100 \%=\text { jumlah sampel } \\
=\text { bilangan tetap }
\end{gathered}
$$

\section{HASIL DAN PEMBAHASAN}

Sebelum menghitung frekuensi penerbitan iklan bank syariah di koran lokal akan disampaikan obyek promosi dan kinerja bank syariah di Banyumas. Dengan mengetahui kedua faktor ini dapat dipetik kaitannya antara strategi promosi dan kinerjanya di masa masa depan. Banyumas merupakan wilayah setingkat kabupaten dengan ibukota Purwokerto dan berpenduduk sebanyak 1.635.909 jiwa dan jumlah penduduk bekerja sebanyak 693.340 jiwa. Kota Purwokerto menjadi pusat pemerintahan, pusat pendidikan, dan pusat jasa dan perdagangan bukan hanya untuk Banyumas, juga untuk kabupaten disekitarnya, yaitu Cilacap dan Purbalingga. Jumlah total sekolah sebanyak 1.331 unit, yang terdiri dari SD/madrasah ibtidaiyah sebanyak 992 unit, SMP/madrasah tsanawiyah sebanyak 206 unit, SMA/MA sebanyak 56 unit, dan SMK sebanyak 77 unit. Jumlah perusahaan yang terdaftar sebanyak 5 perusahaan dagang besar, 118 perusahaan dagang menengah, dan 451 perusahaan dagang kecil (BPS, 2016).

Kinerja bank syariah direkam dari perolehan dana pihak ketiga (DPK) dan pembiayaan, yang dalam penelitian ini dihitung berdasarkan tiga tahun terakhir, yaitu 2014-2016. DPK mengalami pertumbuhan rata-rata 10,97 persen per tahun, dengan perolehan sebanyak Rp.784 miliar (2014), Rp.879 miliar (2015), dan Rp.980 miliar (2016). Ekspansi pembiayaan mengalami penurunan hingga minus, yaitu rata-rata minus 14,5 persen per tahun, yaitu sebesar Rp.933 miliar (2014), Rp.865 miliar (2015), dan Rp.855 miliar (2016) (OJK, 2016). Penelitian ini dimulai dengan menentukan bank syariah dan koran lokal di Banyumas yang akan menjadi obyek penelitian. Terdapat dua jenis bank syariah, yaitu bank umum syariah (BUS) dan unit usaha syariah (UUS). Dalam penelitian ini dipilih empat BUS dan satu UUS. Pemilihan satu UUS karena bank ini merupakan bank milik masyarakat Jawa Tengah, yaitu Bank Jateng Syariah.

Dalam menentukan bank syariah memakai kriteria kecukupan modal dan persepsi masyarakat terhadap bank syariah sehingga terpilihlah Bank Muamalat Indonesia (BMI), Bank Syariah Mandiri (BSM), Bank Jateng Syariah, Bank BRI Syariah, dan Bank BNI Syariah. Bank Muamalat Indonesia (BMI) dikenal 


\section{Islãmadîna \\ JURNAL PEMIKIRAN ISLAM}

sebagai bank syariah pertama di Indonesia, yang beroperasi pada tahun 1991 . Dibandingkan Malaysia dan negara-negara di Timur Tengah dan Afrika, kehadiran bank syariah di Indonesia termasuk terlambat karena di sana sudah mulai diperkenalkan sejak tahun 1970 hingga 1980-an. Kehadiran BMI sudah teruji tangguh karena berhasil lolos dari krisis moneter pada tahun 1998 dan bertahan hingga sekarang, meski kini kepemilikannya didominasi investor asing. Sebagai bank syariah yang sudah memiliki banyak pengalaman tampak dari tayangan iklannya, di media cetak maupun elektronik, telah mengalami pergeseran segmen nasabah, yang sebelumnya khusus membidik pasar umat Islam, menjadi lebih terbuka pada semua kelompok masyarakat tanpa memandang suku dan agama.

Euis Heryati (2014) membuktikan dari penelitiannya mengenai iklan BMI di media massa, terutama televisi, sudah mengarah pada semua kelompok dan bahkan pada salah satu iklan di televisi menampilkan anjing sebagai salah satu pemeran dalam iklan. Jenis iklan yang ditayangkan adalah iklan korporasi dan produk, serta ditayangkan secara nasional, dan terbukti cukup ampuh karena mendekatkan kebutuhan transaksi perbankan pada semua lapisan masyarakat. Guna meningkatkan kualitas layanannya, manajemen berencana menambah kecukupan modalnya sehingga ditargetkan menjadi bank Buku III pada Juni 2017. Kecukupan modal membuat manajemen lebih leluasa dalam melakukan ekspansi bisnisnya, yang dimulai dari kesiapan sarana dan prasarana, sumberdaya manusia, dan strategi pemasarannya (http://finansial.bisnis.com/, 2017).

Hingga sekarang sudah tercatat 4,3 juta nasabah melalui 457 gerai yang tersebar di 33 provinsi di Indonesia. Jaringannya lebih dari 4.000 kantor Pos Online/SOPP di seluruh Indonesia, 1.996 ATM, serta 95.000 merchant debet (http://www.bankmuamalat.co.id/profil-bank-muamalat). Setelah delapan tahun beroperasi sendirian, BMI mendapatkan teman barunya, yaitu Bank Syariah Mandiri (BSM) pada tahun 1999. Krisis moneter pada tahun 1997 menyadarkan banyak pihak bahwa bank konvensional ringkih terhadap krisis, sedangkan bank syariah terbukti imun. Banyak bank konvensional ditutup operasionalnya oleh otoritas keuangan dengan segala tingkat permasalahannya. Otoritas mengambil alih manajemen pengelolaannya untuk disehatkan sesuai dengan peraturan perbankan. Kemudian otoritas melepaskan kepemilikan pemerintah pada bank dengan cara menawarkannya pada investor baru. Hasil dari penjualannya ini disetorkan sebagai pendapatan negara.

Bank Mandiri salah satu yang membeli sebuah bank swasta nasional dan kemudian bank tersebut dijadikan bank syariah dengan nama Bank Syariah Mandiri (BSM). Sejak awal berdiri, jajaran direksinya cukup tanggap dalam membenahi segala kekurangannya dengan tujuan menjaga kualitas layanan pada nasabah. Dukungan pemilik modal terhadap penetrasi pasarnya cukup kuat sehingga cakupan jaringannya menyebar merata ke seluruh Indonesia. Hingga sekarang, bank yang menjadi anak perusahaan Bank Mandiri ini telah memiliki 
773 kantor cabang di seluruh Indonesia dengan jaringan sebanyak 156 ATM. Komitmen pemodal direalisasikan dalam bentuk penambahan modal sehingga makin memperkokoh keberadaannya ditengah masyarakat. Tambahan modal menempatkannya sebagai bank syariah pertama yang masuk kategori Buku III pada tahun 2016. Dalam hal promosi, BSM juga memasang iklan di media cetak dan elektronik dengan mengusung tema tertentu sesuai dengan rencana bisnisnya. Pada tahun 2016, bank lebih fokus pada bisnis ritel sehingga promosinya lebih mengedepankan ritel dan selain memasang iklan juga memperkuat kerjasam dengan berbagai komunitas.

Bank Jateng, banknya wong Jawa Tengah, meresmikan pembukaan kantor unit usaha syariah (UUS) pada 26 April 2008. Kehadirannya untuk memenuhi kebutuhan masyarakat terhadap jasa layanan produk keuangan syariah. Dinilai prospek bisnisnya cukup menjanjikan dan sebagai bentuk komitmen pemilik modal, maka jangkauan layanan terus ditambah dengan kantor cabang Surakarta merupakan kantor cabang pertama di luar Semarang. Kemudian berlanjut hingga sekarang sudah tersebar sebanyak empat kantor cabang syariah, sembilan kantor cabang pembantu syariah, tujuh kantor kas syariah, 145 layanan syariah (office chanelling) yang tersebar diseluruh wilayah Jawa Tengah. Guna meningkatkan pelayanan pada nasabah, nasabah Bank Jateng Syariah dapat melakukan transaksi tarik-setor rekening tabungan di seluruh kantor cabang, kantor cabang pembantu, maupun kantor kas Bank Jateng. Makin besarnya animo masyarakat membuat manajemen meningkatkan kecukupan modal sehingga akan masuk Buku III pada tahun 2017 (http://infobanknews.com, 2017).

Manajemen Bank Jateng menargetkan pelepasan (spin off) Bank Jateng Syariah pada tahun 2018 atau 2019 sesuai dengan Rencana Bisnis Bank (RBB). Disaat itu, aset bank sudah mencapai target Rp.10 triliun dan bila belum terwujudkan pencapaiannya akan segera menggantinya dengan skenario lain dengan asumsi target belum tercapai. Keputusan manajemen yang tidak kalah pentingnya adalah mengikutsertakannya pada pembiayaan proyek-proyek infrastruktur. Hal ini membalikan stigma bahwa bank hanya konsentrasi pada pembiayaan konsumtif. Dalam hal promosi, Bank Jateng Syariah mengikuti rencana induk dari rencana bisnis bank Bank Jateng. Dalam beberapa iklan yang dimuat di koran lokal di Jawa Tengah, materinya lebih mengedapankan branding korporasi, sedangkan produk diserahkan pada masing-masing manajemen.

Bank BRI Syariah hadir ditengah masyarakat pada tanggal 17 November 2008. Bank ini sebelumnya adalah bank konvensional dan setelah diakuisisi Bank BRI, maka diubah menjadi Bank BRI Syariah dengan tujuan menjadi kegiatan perbankan berdasarkan prinsip syariah. Namun demikian, statusnya masih Unit Usaha Syariah (UUS). Seiring dengan perjalanan waktu, manajemen pun terus meningkatkan layanan nasabah melalui pelayanan prima (service excellence) dan menawarkan beragam produk yang sesuai harapan 


\section{Islãmadîna \\ JURNAL PEMIKIRAN ISLAM}

Volume 19, No. 2, September $2018: 41-58$

nasabah dengan prinsip syariah. Pada 19 Desember 2008, Bank BRI melepasnya dan menjadi anak perusahaannya dengan fokus menjadi bank ritel modern terkemuka dengan menghadirkan layanan berkualitas dan beragam produk inovatif. Menjaga inklusifitasnya dengan terus membuka kantor cabang, unit mikro syariah, serta kantor layanan syariah di seluruh penjuru nusantara dengan dukungan sumberdaya insani dan teknologi tinggi dengan harapan dapat diterima dan menjadi pilihan utama masyarakat Indonesia. Per akhir tahun 2015, BRI Syariah telah memiliki 52 Kantor Cabang, 208 Kantor Cabang Pembantu, 11 Kantor Kas, 675 Kantor Layanan Syariah yang tersebar di seluruh wilayah Indonesia. Dalam promosi berpegang pada nilai-nilai inklusif dalam memberikan layanan dan jasa perbankan dan tanpa memperhatikan suku, agama, dan ras (Sara). Model promosinya adalah dengan mengadakan even-even direct sale, iklan di televisi dan koran, memanfaatkan media sosial. Kecukupan modal pun terus ditingkatkan pemegang saham karena sebagai komitmen meningkatkan layanan pada masyarakat. Bank BRI Syariah bertekad masuk kelompok bank umum kegiatan usaha (Buku) III pada tahun ini juga (http://keuangan.kontan.co.id, 206 ).

Tempaan krisis moneter tahun 1997 membuktikan ketangguhan sistem perbankan syariah sehingga menjadi salah satu pendorong pembentukan Unit Usaha Syariah (UUS) BNI Syariah pada tanggal 29 April 2000. Sejak awal pendirian, Bank BNI, yang menjadi induk banknya, sudah berkomitmen akan melepasnya menjadi bank unit syariah (BUS) dalam waktu secepatnya. Pada tanggal 19 Juni 2010, BNI Syariah beroperasi sebagai Bank Umum Syariah (BUS). Membutuhkan waktu cukup panjang dari sejak pertama kali beroperasi dengan UUS menjadi BUS dikarenakan faktor eksternal berupa aspek regulasi yang kondusif yaitu dengan diterbitkannya UU No.19 tahun 2008 tentang Surat Berharga Syariah Negara (SBSN) dan UU No.21 tahun 2008 tentang Perbankan Syariah. Selain itu, sudah tampak kuatnya komitmen pemerintah terhadap pengembangan perbankan syariah. Dalam mempromosikan BNI Syariah pada masyarakat, manajemen melibatkan pihak ketiga dengan mengundang mereka untuk melakukan presentasi strategi promosi bank. Mereka bertugas mempersiapkan konsep strategi, mendesain, memproduksi, dan menempatkan iklan di koran, majalah, banner, reklame, televisi, radio, dan website. Per Juni 2014, jumlah cabang BNI Syariah mencapai 65 Kantor Cabang, 161 Kantor Cabang Pembantu, 17 Kantor Kas, 22 Mobil Layanan Gerak dan 20 Payment Point. Bank yang fokus pada segmen pembiayaan bisnis komersial, ritel, bisnis mikro, dan bisnis treasury dan internasional ini berkomitmen masuk pada Buku III pada tahun ini, pada 2017.

Pada prinsipnya, kelima bank syariah di atas memiliki kebijakan promosi melalui pemasangan iklan di koran dengan jenis iklan korporasi dan produk. Terbukti mereka melakukan pemasangan iklan di koran skala nasional agar dapat menyentuh seluruh lapisan masyarakat dan sebagian kota di seluruh Indonesia. 
Koran lokal pun merupakan media potensial untuk mempromosikan bank syariah pada masyarakat karena cakupannya menyentuh masyarakat tertentu, yaitu dalam lingkup lokal. Di eks karisidenan Banyumas terdapat 25 koran lokal dengan lingkup wilayah Banyumas, Cilacap, Purbalingga, dan Banjarnegara (Taufik Dwi Laksono, 2007). Hasil penelitian Dewan Pers melaporkan bahwa jumlah koran lokal di Jawa Tengah sebanyak 11 koran pada tahun 2010 (Sutrisno, 2011). Pada umumnya pemberitaannya lebih banyak menyentuh masyarakat Purwokerto (Banyumas) sebesar 45 persen, Purbalingga sebesar 25 persen, Cilacap sebesar 15 persen, dan Banjarnegara sebesar 10 persen. Hingga sekarang posisi ini belum banyak berubah yang ditandai dengan jumlah halaman untuk Banyumas antara dua dan tiga halaman, sedangkan wilayah lain hanya satu halaman.

Penentuan media lokal berdasarkan kriteria kemudahan diperoleh dan tingkat popularitasnya. Untuk itu, peneliti melakukan penelusuran disejumlah jalan di kota Purwokerto untuk memastikan koran yang paling mudah ditemukan. Koran Radar Banyumas dan Satelit Post paling mudah ditemukan atau selalu tersedia dibeberapa kios atau loper koran di Jalan Jenderal Soedirman, Jalan Gatot Subroto, Jalan Dukuhwaluh, dan Jalan Bunyamin. Dapat dikatakan, setiap kios atau loper pasti menyediakan kedua koran ini, tetapi belum tentu dengan koran-koran lokal lain. Beberapa koran lainnya adalah koran nasional, tetapi menyisipkan halaman khusus untuk memuat berita lokal, yaitu berita seputar Banyumas. Halaman mereka pun sangat terbatas dan beberapa diantaranya mencampuradukan seluruh jenis berita, terutama kriminal, politik, ekonomi, sosial, dan budaya pada satu halaman saja. Ini berbeda dengan kedua koran yang menjadi obyek penelitian karena intens mempublikasikan berbagai peristiswa ekonomi, politik, sosial, dan budaya seputar Banyumas dalam lembar terpisah. Bahkan mereka memiliki halaman khusus yang diperuntukan sebagai media promosi.

Promosi merupakan suatu keharusan bagi bank syariah untuk mempengaruhi nasabah dan calon nasabahnya. Bauran promosi adalah advertising (iklan), personal selling, sales promotion, public relations, word of mouth, dan direct marketing (Ratnasari, 2011). Dalam penelitian ini peneliti mengkaji promosi bank syariah dengan pendekatan iklan. Iklan merupakan bauran dari promosi. Tujuan iklan adalah sebagai sumber informasi, persuasif, pengingat, menyakinkan pembeli atas produknya. Iklan sebaiknya menjadi pilihan setiap produk, tanpa terkecuali bank syariah, agar lebih dikenal dan makin dekat dengan nasabah dan calon nasabahnya.

Literasi keuangan syariah, khususnya bank syariah, masih terus dilaksanakan hingga pelosok daerah dengan berbagai model promosi. Tujuannya untuk meningkatkan pemahaman masyarakat terhadap bank syariah sehingga minat menabung atau mengakses pembiayaan bank syariah makin tinggi di masa depan. Iklan menjadi salah satu media promosi bank syariah pada calon nasabah dan nasabah setianya di Banyumas. Banyumas merupakan 


\section{Islãmadîna \\ JURNAL PEMIKIRAN ISLAM}

kota jasa karena disini terdapat industri pariwisata, kuliner, perdagangan, serta pendidikan. Tentunya keberadaan bank tidak terpisahkan dari aktivitas masyarakat tersebut dan boleh dikatakan hampir seluruh transaksinya mempergunakan jasa bank.

Bank BMI, Bank Syariah Mandiri (BSM), Bank Jateng Syariah, Bank BRI Syariah, dan Bank BNI Syariah sudah memiliki kantor cabang yang berkantor di Purwokerto. Bank-bank ini merupakan bagian dari bank nasional yang melayani jasa perbankan di wilayah ini. Masa penelitian dipilih pada bulan November-Desember 2016 dan Januari-Februari 2017 yang setara dengan 240 hari atau dua bulan sebelum akhir tahun 2016 dan dua bulan pada awal tahun 2017. Selama masa itu hanya terdapat tiga hari libur nasional dan pada hari itu koran-koran tersebut tidak terbit. Dengan begitu, realisasi penerbitannya sebanyak 237 hari. Berdasarkan pemantauan selama empat bulan itu ditemukan fakta mengenai pemasangan iklan di Radar Banyumas sebagaimana digambarkan sebagai berikut :

Tabel 1:

Frekuensi Penerbitan Iklan di Radar Banyumas

\begin{tabular}{llll}
\hline No. & Bank & Frekuensi & Jenis \\
\hline 1. & Bank BMI & - & - \\
2. & Bank BSM & 2 & Berita \\
3. & Bank Jateng Syariah & - & - \\
4. & Bank BRI Syariah & 2 & Berita \\
5. & Bank BNI Syariah & 1 & Berita \\
\hline
\end{tabular}

Sumber : data hasil penelitian diolah sendiri

Peneliti menemukan informasi mengenai BSM dan Bank BRI Syariah masing-masing sebanyak dua informasi dan Bank BNI Syariah sebanyak satu informasi di Radar Banyumas. Seluruh informasi ini ditemukan pada bulan Februari 2017. Hanya saja, informasi tersebut berjenis berita, yang merupakan hasil liputan atau kutipan dari media lain, mengenai promosi korporasi dan produk yang diselenggarakan kantor pusat. Informasi tentang Bank BMI dan Bank Jateng Syariah dalam bentuk iklan dan berita di koran ini tidak ditemukan. Tentu muncul dugaan apa yang menyebabkannya tidak adanya informasi seputar bank-bank syariah tersebut.

Isu yang diangkat dalam berita itu bersifat nasional karena hasil liputan aktivitas dari kantor pusat. Berita tersebut tidak menyentuh sama sekali mengenai aktivitas masing-masing bank syariah di Banyumas. Kantor cabang bank syariah tidak memasang iklan selama periode penelitian karena peneliti tidak menemukan iklan di koran Radar Banyumas. Bahkan pada momentum khusus seperti Hari Ulang Tahun (HUT) Kabupaten Banyumas yang jatuh pada bulan Februari, dimana banyak perusahaan memasang iklan bersama, tidak ditemukan iklan dari bank-bank syariah. Iklan bersama adalah Radar Banyumas menyediakan ruang (spaces) yang diberikan khusus bagi pemasang iklan dalam 
bentuk ucapan selamat ulang tahun Kabupaten Banyumas. Pemasangnya dari kalangan industri, instansi pemerintah, dunia pendidikan, dan bahkan perorangan. Berdasarkan pemantauan di Satelit Post tergambarkan dalam tabel sebagai berikut :

Tabel 2:

Frekuensi Penerbitan Iklan di Satelit Post

\begin{tabular}{clll}
\hline No. & Bank & Frekuensi & Jenis \\
\hline 1. & Bank BMI & - & - \\
2. & Bank BSM & - & - \\
3. & Bank Jateng Syariah & 1 & Berita \\
4. & Bank BRI Syariah & - & - \\
5. & Bank BNI Syariah & - & - \\
\hline \multicolumn{7}{l}{ Sumber : data hasil penelitian diolah sendiri }
\end{tabular}

Terdapat satu tulisan tentang Bank Jateng Syariah. Jenis tulisan adalah berita. Periode pemuatannya pada bulan Januari 2017. Tidak ditemukan iklan dan berita tentang Bank BMI, Bank BSM, Bank BRI Syariah, dan Bank BNI Syariah. Tentunya banyak dugaan yang timbul atas ketiadaan info seputar bank-bank syariah itu di koran ini. Bank syariah lain tidak memasang iklan maupun tidak terdapat berita seputar kegiatan mereka di Banyumas. Koran ini memiliki halaman khusus bisnis yang memuat berbagai kegiatan atau promosi mengenai otomotif, selular, properti, perbankan, dan sebagainya. Namun, tidak ditemukan berita mengenai bank syariah. Begitu pula dengan iklan bersama ucapan Hari Ulang Tahun (HUT) Kabupaten Banyumas yang jatuh pada bulan Februari di Satelit Post tidak dimanfaatkan bank syariah untuk berpartisipasi menjadi pemasang iklan. Iklan ini hanya diisi industri lain, sektor pendidikan, instansi pemerintah, dan perseorangan.

Hasil penelusuran juga membuktikan bahwa informasi itu pun bukan dalam jenis iklan, melainkan berita. Sebagaimana diketahui bahwa jenis-jenis iklan adalah iklan baris, display, dan advetorial. Iklan advetorial adalah iklan produk/jasa yang disajikan dalam bentuk berita/narasi. Untuk membedakan berita hasil liputan dengan iklan advertorial sebenarnya cukup mudah karena diakhir tulisan terdapat kode tertentu, seperti $(* a d v)$, yang berarti berita itu adalah iklan advetorial. Berita hasil liputan pada kode akhirnya merupakan kode penulis atau wartawan yang bertugas meliput kegiatan tersebut. Dikarenakan tidak ada iklan bank syariah di kedua koran tersebut, maka peneliti tidak perlu membuat persentase frekuensi pemuatan iklan dengan rumus :

$$
\begin{aligned}
& \mathrm{P}=f / n \times 100 \% \\
& \text { Keterangan : } \\
& \begin{aligned}
\mathrm{P}=\text { Persentase } \\
\mathrm{f}=\text { Frekuensi } \\
\mathrm{n}=\text { Jumlah Sampel }
\end{aligned} \\
& 100 \%=\text { Bilangan tetap }
\end{aligned}
$$

Persentase ini bertujuan untuk mengetahui frekuensi pemasangan iklan bank-bank syariah tersebut di kedua koran lokal, mengetahui jenis iklan yang 


\section{Islãmadîna \\ JURNAL PEMIKIRAN ISLAM}

dipilih, serta mengetahui konten iklan pada koran Radar Banyumas dan Satelit Post selama periode November 2016-Februari 2017. Memperhatikan jenis tulisan pada kedua koran tersebut adalah berita, maka dapat dipastikan bahwa seluruh bank syariah yang menjadi obyek penelitian tidak pernah memasang iklan di koran lokal tersebut. Bank syariah tidak memakai iklan sebagai media untuk memperkenalkan dan menyakinkan produk jasanya pada nasabah maupun calon nasabah. Pada momen khusus pun, iklan bank-bank syariah tidak muncul dalam bentuk apa pun. Tentunya pimpinan kantor cabang bank syariah memiliki alasan kenapa tidak memasang iklan ucapan selamat di koran. Dikarenakan penelitian ini hanya untuk mengetahui frekuensi pemuatan, maka penulis tidak melakukan wawancara dengan kepala cabang dari masing-masing bank. Kemudian penulis mengaitkan hasil penelitian ini dengan penelitian-penelitian lain yang masih ada hubungannya sehingga menghasilkan suatu gambaran lengkap mengenai iklan dan bank syariah.

Hasil penelitian Muhammad Haris (2015) menunjukan bahwa sumber informasi bank syariah secara berurutan adalah dari teman/orang lain, keluarga/saudara, dan kemudian dari iklan di media cetak, lainnya, internet, dan iklan media elektronik. Berdasarkan penelitian itu dapat diduga bank syariah di Banyumas tidak memasang iklan di media cetak karena mengandalkan publikasi dari teman/orang lain dan keluarga/saudara. Dugaan ini lebih beralasan dan dapat dipertanggungjawabkan secara akademik karena iklan media elektronik dan internet relatif mahal dan hanya mungkin dilakukan kantor pusat. Dengan begitu, kemungkinan bank syariah memanfaatkan publikasi gratis dari teman/orang lain dan keluarga/saudara sehingga terjadi suatu keingintahuan mereka untuk memanfaatkan layanan bank syariah. Euis Heryati (2014) mengatakan bahwa iklan perbankan lebih bernuansa korporasi karena produknya berupa jasa keuangan dan bersentuhan langsung dengan masyarakat. iklan sebagai media komunikasi berperan pula dalam membidik calon nasabah dari kalangan nonmuslim dan multicultural. Ini juga sangat menguatkan citra bank syariah bahwa bank syariah bukan hanya ditujukan pada kelompok Islam, melainkan pada semua lapisan masyarakat.

Dalam penelitian ini memang tidak dilakukan wawancara dengan kepala cabang bank yang menjadi obyek penelitian karena awal dari penelitian adalah hanya untuk mengetahui frekuensi pemasangan iklan. Temuan lapangan adalah tidak ada iklan dari obyek penelitian. Informasi mengenai bank syariah di Radar Banyumas dan Satelit Post adalah berita, yang merupakan hasil liputan wartawan pada suatu acara atau even di kantor pusat bank syariah. Menurut Lenny Meyrin Evelyn Lengkey (2014), kurang antusiasnya perusahaan-perusahaan besar memasang iklan koran lokal kurang aktifnya beberapa staf pemasaran iklan. Mereka kurang komunikatif dalam menarik pelanggan untuk memberikan sesuatu yang lebih dari iklan yang akan ditayangkan. Dadang Rahmat Hidayat, dkk (2014) mengatakan bahwa koran lokal memiliki banyak strategi untuk mendapatkan iklan. Strategi setiap koran berbeda-beda yang disesuaikan dengan kondisi, lokasi, competitor, dan 
segmen. Dengan begitu, Ardyan Hartiawan (2015) menyarankan pada koran lokal agar melakukan promosi, yang dirancang dengan baik dan mengikuti perkembangan media teknologi terkini, sehingga diharapkan penjualan kolom iklam mengalami peningkatan di kemudian hari. Masih menurut Lenny, sebenarnya koran masih menjadi rujukan masyarakat lokal untuk mendapatkan informasi mengenai berbagai macam berita bukan hanya berita tentang politik, kriminalitas, dan kejadian alam dalam lingkup lokal maupun nasional. Terbukti, hasil penelitian Melina Banggawaliman (2013) melaporkan adanya peningkatkan loyalitas nasabah tabung BRI Simpedes pada Bank BRI Cabang Samarinda setelah pemangsan iklan di koran lokal dan televisi, meskipun iklan tersebut produksi manajemen kantor pusat.

Martutik (2013) mengatakan bahwa efek iklan pada publik tidak bisa dilepaskan dari kelebihan media cetak, termasuk koran, yang mampu menyampaikan pesan yang kompleks dan detil terhadap suatu produk, serta menjangkau masyarakat luas dan latar belakang berbeda. Namun demikian, Melina Banggawaliman (2013) mengingatkan bahwa berita bisa juga menjadi publisitas yang memiliki kredibilitas tinggi dibandingkan iklan sehingga efeknya pada publik tentu besar. Apalagi berita tidak perlu mengeluarkan biaya pemasangan iklan. Taufik Dwi Laksono (2007) menyarankan pada bagian promosi koran lokal yang berkantor pusat di Purwokerto agar lebih aktif menjemput calon pemasang iklan dengan penawaran yang kreatif dan inovatif. Bagaimana pun koran merupakan industri kreatif yang menjadi ruhnya dalam menjembatani pemasang iklan atau pengiklan dengan pembaca.

Tidak dapat dipungkiri bahwa pemasang iklan pun mempertimbangkan oplah koran dalam memutuskan pasang iklan di koran tertentu. Koran yang sudah memiliki merek (brand) terkenal akan lebih mudah mendapatkannya, sebaliknya yang belum terkenal perlu perjuangan keras untuk menyakinkan calon pengiklan. Lebih lanjut Taufik memperkirakan pasar iklan di Purwokerto sebenarnya cukup potensial karena pasar ini belum digarap koran nasional. Biro-biro iklan nasional masih memandang sebelah mata Purwokerto karena biaya promosi dinilai mahal karena untuk memperkenalkan produk di Jawa bagian tengah ini sedikitnya membutuhkan tiga koran lokal. Padahal promosi di Jakarto, Bogor, Tangerang, dan Bekasi cukup memasang di satu koran nasional. Disisi lain, ini adalah peluang bisnis yang cukup potensial bagi koran lokal untuk mendapatkan iklan karena ceruk ini belum digarap koran nasional. Disarankan masing-masing koran lebih gencar mempromosikan diri pada calon pengiklan dengan ide-ide kreatifnya agar menyakinkan pengiklan sehingga terbuka baginya menjadi opinion leader dan market leader dalam hal promosi ke Jawa bagian tengah ini.

Berdasarkan pemaparan di atas terdapat dua sisi yang saling berkaitan, yaitu bank syariah belum memanfaatkan koran lokal untuk menjadi media promosi produknya. Sisi lain koran lokal diduga belum maksimal menyakinkan bank syariah bahwa iklan kreatif yang ditawarkannya dapat menyentuh seluruh 


\section{Islãmadîna \\ JURNAL PEMIKIRAN ISLAM}

lapisan masyarakat di Banyumas. Menyimak pertumbuhan DPK dan pembiayaan industri perbankan syariah nasional dengan lingkup Banyumas dapat dijabarkan sebagai berikut : pertumbuhan DPK nasional sebesar 20,83 persen, sedangkan tingkat Banyumas hanya 10,97 persen. Pertumbuhan pembiayaan nasional sebesar 16,40 persen, sedangkan pada tingkat Banyumas justru minus 14,5 persen. Tentu saja tidak optimalnya pertumbuhan DPK dan pembiayaan bank syariah di Banyumas harus mendorong mereka untuk lebih menggencarkan promosinya. Perlu dipilih model promosi yang tepat karena belum terpenuhinya pertumbuhan itu disebabkan masih banyaknya masyarakat yang belum memahami bank syariah.

Pertimbangkan promosi dengan biaya murah, lingkup yang massal, dan materi promosi langsung mengenai obyeknya. Bauran promosi adalah advertising (iklan), personal selling, sales promotion, public relations, word of mouth, dan direct marketing. Bank syariah dapat memilih bauran yang tepat sesuai dengan anggaran yang tersedia, namun menyasar pada obyek yang masif. Terdapat kelebihan dan kekurangan dari iklan koran (Cecep Supriadi, 2013). Kelebihannya adalah menjangkau banyak orang pada geografis tertentu, fleksibel dalam materi, grafis yang menarik, paparan iklan tidak terbatas, serta cepat diterima obyek promosi. Kekurangannya adalah biaya relatif mahal, kreativitas terbatas, koran dibaca hanya sekali, reaksi kompetitor sangat cepat bila membaca iklan dari perusahaan sejenis, kemungkinan penurunan pembaca. Dikarenakan selama masa penelitian tidak ditemukan iklan dapat diduga bahwa bank syariah memakai bauran promosi lain dan condong pada personal selling, sales promotion, word of mouth, dan direct marketing. Peneliti tidak memasukan public relations karena bauran ini sangat tidak lepas dari keterlibatan koran.

Pada bulan November 2016 terdapat even bersama bank syariah dengan menggelar Expo Bank Syariah. Seluruh bank syariah dan lembaga keuangan syariah berpartisipasi dalam rangka memperkenalkan produk lembaga keuangan syariah pada masyarakat. Even ini menggabungkan bauran personal selling, sales promotion, dan direct marketing. Word of mouth tidak dimasukan dalam kelompok ini karena bauran ini lebih mengedepankan pengalaman sukses seorang nasabah bank syariah ditularkan pada teman, kerabat, atau orang yang dikenalnya sehingga orang itu bergabung pada bank syariah.

Expo merupakan even yang melibatkan seluruh bank syariah dalam upaya memperkenalkan produknya pada masyarakat. Kebersamaan ini dapat diterapkan secara berkelanjutan karena dapat menekan biaya promosi, namun hasilnya ditindaklanjuti masing-masing bank. Kebersamaan ini dapat dilanjutkan pada pemasangan iklan di koran lokal dan peneliti menemukan iklan bersama ini pada bulan Maret 2017, dimana bank syariah atas nama Asosiasi Bank Syariah Indonesia (Asbisindo) wilayah Eks Karesidenan Banyumas. Ini suatu langkah strategis karena iklan bersama sudah berkembang sejak lama dengan kasus pada iklan ATM BCA yang merupakan hasil aliansi 
strategis Bank BCA dengan Citibank (Hifni Alifahmi, 2005).

Kemitraan ini lebih menguntungkan daripada saling berperang karena sebenarnya masyarakat akan memilih dengan cerdas produk yang sesuai dengan kebutuhannya. Kemitraan ini, menurut Fahmi, dibutuhkan dalam segala kondisi, baik dalam situasi krisis maupun normal, karena hal ini memberikan buah pada bank syariah dalam bentuk efisiensi biaya, kecepatan penetrasi pasar, perluas jaringan, menjaga kesetiaan pelanggan, dan sinergi merek. Namun Fahmi mengingatkan agar iklan harus mengandung nilai kreatif, menjual, dan juga nilai berita karena ditemukan banyak iklan tetapi tidak menjual nilai berita. Hal ini berakibat masyarakat sebagai obyek promosi hanya ingat slogannya, tetapi tidak mengingat produk bank syariah, dan apalagi sampai membeli atau memanfaatkan jasanya. Eddy Kurnia (2010) mengatakan bahwa Telkom menghindari iklan yang sekadar disenangi masyarakat tanpa ada efek membeli produk-produknya. Karena itu, iklan-iklannya di media elektronik, media online, media cetak, dan media luar harus mendongkrak penjualan produk sehingga pendapatan atas penjualan sepadan dengan biaya yang sudah dikeluarkannya.

Dalam lingkup masing-masing lembaga, masing-masing bank syariah dapat mengirimkan siaran pers pada Radar Banyumas dan Satelit Post sebanyak mungkin dengan mengangkat isu-isu yang aktual, yang berkaitan dengan produk atau kinerja banknya. Berkaca pada pengalaman Telkom, menurut Eddy, selalu rutin mengirimkan siaran pers ke berbagai media dengan jumlahnya sebanyak 150 siaran pers selama tahun 2009. Hasilnya adalah sebagian media memuatnya secara utuh, ada pula yang dijadikan berita ringkas, tetapi ada pula yang tidak menurunkannya sama sekali. Telkom memetik keuntungan besar ketika siaran pers menjadi berita pada koran tertentu karena masyarakat dapat menilai isu-isu aktual terhadap produk dan korporasi pada perusahaan telekomunikasi terbesar di Indonesia ini. Bahkan siaran pers dapat menjadi pelurus informasi yang mungkin keliru dipersepsikan oleh masyarakat.

Mengenai isu yang disampaikan pada siaran pers disarankan jangan dengan pendekatan agama lagi karena pada dasarnya bank syariah bukan milik agama tertentu saja, melainkan milik semua orang yang ingin membutuhkan layanan bank tanpa riba. Menurut Rinda Asytuti (2012), isu-isu yang diangkat dalam promosi bank syariah jangan melalui pendekatan sentimen keagamaan lagi karena masyarakat hanya ingin mengetahui produk bank syariah sehingga pendekatannya pun perlu dalam tataran ekonomi, tetapi tetap seiring dalam nilai-nilai syariah. Karena itu, lanjut Rinda, apa yang disampaikan dengan pendekatan ekonomi ini lebih dapat diharapkan menciptakan persepsi positif dalam benak masyarakat sebagai nasabah dan calon nasabah. Hal ini membuat masyarakat bersedia memanfaatkan jasa layanan bank syariah sesuai dengan kebutuhannya.

Pada akhirnya, bank syariah perlu melakukan promosi dengan gencar melalui berbagai bauran promosi, terutama melalui iklan koran dan bila hal ini 


\section{Islãmadîna \\ JURNAL PEMIKIRAN ISLAM}

dinilai mahal dapat ditempuh dengan membuat kerjasama dengan asosiasi sehingga biaya promosinya menjadi rasional. Pemasangan iklan yang gencar bertujuan meningkatkan jasa transaksi perbankan syariah di Banyumas karena berdasarkan data yang dikeluarkan Otoritas Jasa Keuangan (OJK) terjadi perlambatan perkembangan bank syariah di Banyumas.

\section{SIMPULAN}

Berdasarkan hasil penelitian yang telah dilakukan dapat disimpulkan sebagai berikut Bank BMI, Bank BSM, Bank Jateng Syariah, Bank BRI Syariah, dan Bank BNI Syariah tidak memasang iklan di koran Radar Banyumas dan Satelit Post selama periode November 2016 hingga Februari 2017. Bank syariah yang menjadi obyek penelitian juga tidak memanfaatkan momentum hari ulang tahun Kabupaten Banyumas untuk memasang iklan bersama ucapan selamat ulang tahun atau dirgahayu Kabupaten Banyumas yang dirayakan pada bulan Februari 2017. Terdapat dua berita Bank BSM dan Bank BRI Syariah, serta satu berita Bank BNI Syariah di Radar Banyumas, dan satu berita Bank Jateng Syariah di Satelit Post. Penelitian tidak dapat melakukan frekuensi perhitungan pemasangan iklan karena seluruh bank syariah yang menjadi obyek penelitian tidak memasang iklan di kedua koran tersebut.

\section{DAFTAR PUSTAKA}

Andromedha Wisnu Nugroho. 2013. Analisis Pengaruh Efektivitas Iklan Terhadap Keputusan Pembelian Sepeda Motor Matik Yamaha di Semarang. Eprints.dinus.ac.id/8615. Diakses pada 25 Oktober 2016.

Anggun Pratama Setya. 2017. Strategi Komunikasi Pemasaran Suratkabar Harian Kaltim Post dalam Menghadapi Persaingan di Kota Samarinda. eJournal Ilmu Komunikasi 2017, 5 (1) : 221 - 234 ISSN 2502-597X, ejournal.ilkom.fisip-unmul.ac.id

Ayu Satya Kartika dan A.A Gede Agung Artha Kusuma. 2016. Peran Efektivitas Iklan dalam Memediasi Daya Tarik Iklan Terhadap Brand Attitude pada Iklan Merek Aqua (Studi Pada Konsumen Aqua) di Kota Denpasar. E-Jurnal Manajemen Unud, Vol. 5, No.1, 2016: 176-206

Cecep Supriadi. 2013. Kelebihan dan Kekurangan Berbagai Media Periklanan. http://www.marketing.co.id/kelebihan-dan-kekurangan-berbagai-media-p eriklanan/

Dadang Rahmat Hidayat, Aceng Abdullah. 2014. Fenomena Iklan Baris Kesehatan di Suratkabar Lokal. Jurnal Kajian Komunikasi, Volume 2, No. 2, Desember 2014,

Eddy Kurnia. 2010. Komunikasi dalam Pusaran Kompetisi. Penerbit Republika. Jakarta.

Hifni Alifahmi. 2005. Sinergi Komunikasi Pemasaran : Integrasi Iklan, PR, dan Promosi. Quantum Bisnis dan Manajemen. Jakarta.

Kristevel Mokoagow. 2016. Peranan Surat Kabar Dalam Menumbuhkan Minat Baca Remaja di Kecamatan Singkil Kota Manado. e-journal "Acta Diurna" Volume V. No.2. Tahun 2016 
Kunthi fahmar sandy. 2017. Kinerja Perbankan Syariah 2016 Tumbuh Positif. https://ekbis.sindonews.com/read/1184537/178/kinerja-perbankan-syariah -2016-tumbuh-positif-1488390865

Lenny Meyrin Evelyn Lengkey, dkk. 2014. Peranan Komunikasi Pemasaran dalam Meningkatkan Minat Pengguna Iklan di Harian Komentar Manado. Journal “Acta Diurna” Volume III. No.3. Tahun 2014

Martutik. 2013. Isi Pesan Persuasif Dalam Advetorial Media Massa Cetak. Jurnal Bahasa dan Seni, Tahun 41,Nomor1, Februari 2013.

Melina Banggawaliman. 2013. Komunikasi Pemasaran Produk Simpedes di Bank Rakyat Indonesia Cabang Samarinda. eJournal Ilmu Komunikasi, 2013, 1(4) : 268-277

Nila Kasuma Dewi, dkk. 2012. Pengaruh Iklan, Citra Merek, dan Kepuasan Konsumen Terhadap Loyalitas Konsumen dalam Menggunakan Vaseline Hand dan Body Lotion di Kota Padang (Studi Kasus PT Unilever Cabang Padang). Jurnal Manajemen dan Kewirausahaan, Volume 3, Nomor 2, Mei 2012

Petrus Suryadi Sutrisno. 2011. Fenomena Kebangkitan Industri Pers Daerah/Media Lokal. Jurnal Dewan Pers. Edisi No.5, Mei 2011.

Rinda Asytuti. 2012. Kritik Terhadap Pemasaran Bank Syariah (Pendekatan Eksperiental Marketing. Jurnal Hukum Islam (JHI) Volume 10, Nomor 1, Juni 2012 http: e-journal.stain-pekalongan.ac.id/index.php/jhi ISSN (P): $1829-7382$

Taufik Dwi Laksono. 2007. Analisa Pendirian Bisnis Surat Kabar.Teodolita Vol. 8, No.1., Juni 2007:15-23. Unwiku

Yanuar Nugroho, Dinita Andriani Putri, Shita Laksmi. 2012. Memetakan Lansekap Industri Media Kontemporer di Indonesia. Centre for Innovation Policy and Governance. Jakarta.

2007. Cetak Biru Pengembangan Perbankan Syariah Indonesia. Bank

Indonesia. Jakarta.

2012. Tiga Masalah Terbesar di Bank Syariah. http://bisniskeuangan.kompas.com/read/2012/08/13/15282835/Tiga.Masal ah.Terbesar.di.Bank.Syariah 2007. Cetak Biru Pengembangan Perbankan Syariah di Indonesia. Bank Indonesia. Jakarta

. 2014. Bank Syariah Perbesar Market Share Di Purwokerto. http://semarang.bisnis.com/read/20150416/12/78262/bank-syariah-perbes ar-market-share-di-purwokerto. Diakses pada 28 November 2016. .2015. Ini 7 Masalah Bank Syariah. m.tempo.co/read/news/2015/11/22/087721104/ini-7-masalah-bank-syaria h. Diakses pada 28 November 2016.

2016. OJK: Pangsa pasar perbankan syariah $4,87 \%$. www.antaranews.com/berita/546856/

ojk-pangsa-pasar-perbankan-syariah-487. Diakses pada 28 November 2016. . 2016. Statistik Perbankan Indonesia 2016. Maret, Volume 14, No. 4. 


\section{Islãmadîna}

Otoritas Jasa Keuangan. Jakarta.

2016. BSM Menjadi Bank Syariah Pertama Masuk BUKU III. https://www.syariahmandiri.co.id/2015/11/bsm-menjadi-bank-syariah-perta ma-masuk-buku-iii/

. 2016. Dua bank syariah bertekad naik kelas. http://keuangan.kontan.co.id/news/dua-bank-syariah-bertekad-naik-kelas 2016. Rapor Bank Besar 2017; Gelombang PHK Belum Selesai. http://infobanknews.com/rapor-bank-besar-2017-gelombang-phk-belum-s elesai/

2017. Bank Muamalat Ke BUKU III Sebelum Juni 2017. http://finansial.bisnis.com/

$\mathrm{read} / 20170209 / 90 / 627449 /$ bank-muamalat-ke-buku-iii-sebelum-juni-2017 